\title{
The Phenomenon of Self-Actualization of Young Volunteers at The IYALE Institute And Its Implications For Individual Resilience
}

\author{
M Z N Lubis ${ }^{1}$, A I Munandar ${ }^{2}$ \\ ${ }^{1,2}$ Universitas Indonesia, Jakarta \\ 1muhammad.zuchri@ui.ac.id, ${ }^{2}$ adis.imam@ui.ac.id
}

\begin{abstract}
This study analyzes the phenomenon of self-actualization of young volunteers at the IYALE Institute (Indonesian Youth and Leader Empowerment) and its implications for individual resilience. Specifically, this study aims to find out how the self-development process of young volunteers at the IYALE along the factors that can support and become obstacles. Then from the phenomenon of self-actualization will have implications for the individual resilience of young volunteers at the IYALE. This study uses qualitative methods that are processed based on observations of social phenomena and symptoms. The data sources of this study were divided into primary sources and secondary sources. The results of this study indicate that young volunteers at the IYALE have been able to meet basic needs so that the process of self-actualization goes well. Nevertheless there are several factors that hinder the process of selfactualization, although on a very small scale. The process of self-actualization that is continuously being developed by young volunteers at the IYALE has implications for individual resilience. The implications are explained in the form of individual resilience values.
\end{abstract}

Keywords: Self-Actualization, Young Volunteers, Individual Resilience

\section{INTRODUCTION}

In the Law of the Republic of Indonesia Number 40 of 2009, in Chapter I General Provisions Article 1 states that youth are citizens aged 16 years to 30 years. One of the youth organizations in Indonesia that helped realize the goals of this nation is the Indonesian Youth and Leader Empowerment (IYALE) Institute. IYALE Institute is a youth organization that was established with the aim of forming Indonesian young people who are highly committed in improving the quality of themselves as future leaders for a prosperous and happy Indonesia. IYALE Institution was established in South Tangerang, Banten Province on October 20, 2017.

The vision of IYALE Institute is to become a youth organization that enhances the role of Indonesian youth as national leaders in the future with a nationalist spirit, and upholds the values of Pancasila and diversity. Pancasila as a guideline for the life of the nation and state must meet the needs of the times, then it is developed with the spirit of Unity in Diversity in a continuous moral development.

One of the programs run by the IYALE Institute is the Indonesian Youth Social Expedition (IYSE). IYSE is an agenda of community service and empowerment to become the foremost representative of Indonesia's leading regions so it can enrich insights on the diverse 
nature and culture of Indonesia, develop themselves and make positive contributions as a tangible manifestation of patriotism, training leadership and independence in various scientific fields. The last dedication carried out by the IYALE Institution was in Pangandaran from 1 to 10 August 2018, in Toraja from 11 to 22 August 2018 and Wakatobi from 25 August to 9 September 2018. At the location of the service, the volunteers will run a service field that includes education, health, social and environment as well as the creative economy and tourism. Generally, volunteers are undergraduate students. The ten-day service period that had to be passed by the volunteers demanded that they live far from their parents and family. They are also faced with a new social environment and tend to be plural.

Based on the background, the researchers intends to know the phenomenon of selfactualization of IYALE Institute volunteers and its implications for the individual resilience of the volunteers. The basic theory used in this study is the theory of the basic needs of Abraham Maslow. According to him, the understanding of needs is the behavior of every individual based on the principle of desire and organized between one another [1].

The psychologist Abraham Maslow, in his book Hierarchy of Needs (1943) [2] uses the term self actualization as the highest achievement of a human being in meeting his needs. Maslow found that regardless of one's ethnicity or origins, every human being experiences stages of increasing needs or achievements in his own life. These needs include four main things namely physiological needs, security and safety needs, the need for a sense of social ownership and love also the need for appreciation (esteem needs).

After analyzing the phenomenon of self-actualization of volunteers, the study is about individual youth resilience is carried out as an implication of the process of self-actualization. The concept of personal endurance according to Raharjo is derived from the concept of national endurance, which starts at the national level and then descends into the personal self of each individual [3]. The study of individual resilience is so important as Soemarno Soedarsono (1997) from the Republic of Indonesia's National Resilience Institute in the book Personal Resilience and Family Resilience as a Base for National Resilience. According to Soemarno, humans as individuals need to develop themselves [4].

Soedarsono further described the characteristics of young people who have individual resilience, namely having self-confidence and holding to the principle, free from a sense of dependency but longing for togetherness, having a dynamic, creative and unyielding spirit and prioritizing the public interest rather than personal interests.

\section{RESEARCH METHOD}

In this study a qualitative method was used as Kaelan's opinion (2012) was processed based on observations of social phenomena and symptoms related to IYALE Institute volunteers [5]. Muhammad Idrus in the book Social Research Methods (2009) explains that qualitative research has the characteristic of observing informants as research subjects directly in their daily environment. For this reason, qualitative researchers as far as possible interact closer to the life world of informants, observing and following the flow of their activities [6].

This study took place at the IYALE Institute secretariat located at Jl. Puri Intan Number 15C, Pisangan, East Ciputat, South Tangerang City, Banten Province. Research data collection is divided into primary and secondary data groups. Primary data uses a triangulation technique that combines several data collection techniques namely in-depth interview and observation.

Data is taken from IYALE Institute volunteers and management. Through observation techniques the researcher observes directly on the objects in the research namely the 
volunteers and the program activities scheduled and implemented by the volunteers. While secondary data comes from literature studies, documentation and information from print and electronic media. Literature study serves to define several concepts related to research [7].

Related to the process of data analysis, Bogdan in Sugiyono (2013) states that data analysis is the process of finding and compiling data obtained from interviews, field notes, and other materials systematically, so that they are easily understood and findings can be shared with others [8]. Analysis of the data in this study using the model of Miles and Huberman explained by Purwanto (2010) that this activity consists of data reduction, data presentation and then conclusions can be drawn as a whole data [9].

\section{RESULTS AND DISCUSSION}

Basically, the self-actualization process of IYALE Institute volunteers referred to in this research is an effort to fulfill their basic needs in accordance with the concept of Abraham Maslow.

First, physiological needs which is the most basic needs for every person, namely the needs to sustain his life physically. The needs are like the need for food, drink, shelter, sleep and oxygen (clothing, food, shelter). As the Ministry of Youth and Sports program is quoted in Muhammad Iskandar Zulkarnain (2015) youth who have been able to meet their basic needs will find it easier to develop themselves. Youth development is carried out in order to improve the spirit of leadership, entrepreneurship, and youth pioneering, so that in turn can give birth to young people who are progressive young people who have character, capacity, and competitiveness [10].

During the community service program, the volunteers lived in the homes of local residents whose approval had been sought. Before the program took place, the management of IYALE Institute first conducted a survey with the intention of approaching and communicating with the community and local leaders to provide shelter for the volunteers in quite comfortable conditions.

Gusnurli Sajidin Lingu Lembah volunteer who came from Palu, Central Sulawesi said the approach with the community also really helped them in meeting food needs at the place of service. From the experience he told, he often and often get food assistance from residents such as fruits, sea catches from the community and food cooked directly by the local community. From the information the researcher got, it can be stated that these most basic needs (shelter and food) can be fulfilled well by the volunteers.

Second, security and safety needs. After sufficient physiological needs are satisfied, what Maslow refers to as needs for security. The need for security includes physical security, stability, dependency, protection and freedom from threatening forces such as crime, war, terrorism, disease, fear, anxiety, danger, riots and natural disasters [11]. And psychological needs that threaten mental conditions such as not being ridiculed, not humiliated, not stressed, and so forth. The need for security is different from physiological needs because these needs cannot be totally met. Humans can never be fully protected from the threats of meteors, fires, floods or other dangerous behavior of others.

Based on the conditions on the ground, the volunteers felt safe because of the trust they also gained from the local community. Khansa Orida Putri, a volunteer from the Province of Aceh said the experience and role of the organization she had participated in helped her in communication and gain trust and security from their service environment.

Previously, Khansa had joined the Student Executive Board of the Faculty of Agriculture, Syiah Kuala University, serving as the Secretary of the Field. Currently she also 
serves as General Treasurer of Himatekh (Agricultural Product Technology Student Association) Unsyiah. She has also joined the Unsyiah Faculty of Agriculture Entrepreneurship UKM for 1 year. Also active in the HMPPI (Indonesian Food Concern Students Association) as the central board. At present she is also a member of Putroe Phang Unsyiah Art and PPI (Purna Paskibraka Indonesia) Bireuen Regency, Aceh.

Not only that, security at the service location is also guaranteed by the night patrol which is carried out alternately by the community and volunteers at the location. Only one volunteer told me that in his place of residence still heard the sound of wolves and wild dogs because of its location in the interior. However, security is guaranteed by the local Village Head. Regarding the IYALE secretariat at the location of the service there is indeed no. But to maintain security collectively, the volunteers ( 5 people in 1 location) determine the initiative base camp in the service area. They use this basecamp for meetings and discuss work program issues.

A strong togetherness factor also helps create a sense of security at the service location. Before being deployed to the location, IYALE trains volunteers to always Unite and maintain team cohesiveness. The surrounding community is also very concerned with the volunteers. It was proven when one of the volunteer friends lost his camera during a visit to Iboih, one of the places of dedication, the community was very concerned to join in the search and the response was fast.

This statement proves that the volunteers have been able to meet the need for a sense of security so that in their daily activities, especially in the service they live can be carried out with a feeling of calm, comfort and freedom from worry.

Third, the need for a sense of social ownership and affection (social needs) [12]. If the physiological needs and the need for security have been fulfilled, then the need for love, affection and belongingness has emerged. These needs include encouragement to be needed by others so that he is considered a member of his social community. Forms of meeting these needs such as friendship, the desire to have a partner and offspring, the need to be close to family and interpersonal needs such as the need to give and receive love.

The volunteers embody affection among themselves by telling stories, exchanging ideas and joking. In their spare time, they fill their time by telling each other's life stories or getting to know each other better. Thus, harmony between them can be formed by itself. Some of the attitudes they adopt include good and unselfish communication with one another.

Rifqi Syifa'ul Qolbi comes from the city of Surabaya, East Java, one of the volunteers with special needs feels affection among the volunteers. He certainly realizes many things that his friends dislike about him but other volunteers can tolerate his condition. When joining the community service program last year, he became the youngest volunteer (age 18 years). Even at the beginning of his recruitment he did not tell the committee and other volunteers that he had special needs. He felt protected and cared for by other volunteers.

Based on the statements of the volunteers considered that the need for a sense of belonging and love had been fulfilled by the volunteers. This is proven by good interactions with fellow volunteers and relationships with the surrounding community.

Fourth, the need for esteem. After the needs of being loved and possessed are fulfilled, then man will be free to pursue his ego's needs for the desire to excel and have prestige. Maslow found that every person who has two categories regarding the need for appreciation, namely lower and higher needs. Low need is the need to respect others, the need for status, fame, recognition, attention, reputation, appreciation, dignity, even domination. Higher needs are needs for self-esteem including feelings, beliefs, competencies, achievements, mastery, 
independence and freedom. Once humans can fulfill a need for appreciation, they are ready to enter the gate of self-actualization, the highest need found by Maslow.

From observations made by researchers it can be assessed that there is an interrelated relationship between self-esteem that volunteers make towards themselves with the appreciation given by the community towards them. As stated Alfred Adler in Goble (1987) that someone who has enough self-esteem will be more confident and able to be more productive creativity. Conversely, if their self-esteem is lacking, they will always be overcome by feelings of inferiority and a sense of helplessness, which in turn can lead to feelings of hopelessness and neurotic behavior [13].

Fifth, the need for self-actualization. The last level of basic human needs according to Maslow is self-actualization, that is the need to prove and show themselves to others. At this stage, a person develops as much as possible all the potential he has. The need for selfactualization is a need that does not involve balance, but involves a continuous desire to fulfill potential.

According to some IYALE volunteers, it is very important to fulfill basic human needs in order to support their personalities in a better direction so that everyone can optimize their abilities to help other people's lives in other words, their lives can be said to have been actualized if they can be beneficial to others.

Furthermore, based on interviews conducted with informants and observers of researchers in the field, some volunteer activities can be described that reflect their selfactualization process:

1. Able to meet his physiological needs with personal abilities and expertise.

2. Collaborate and cooperate with local residents.

3. Establish and maintain good communication with fellow volunteers and with the local community.

4. Able to make programs that can be followed and implemented by the community.

5. At the location of the service, they are able to look after themselves and there is no threat from their environment.

6. Able to establish solid unity and togetherness between fellow volunteers and the community.

7. Able to build harmonious relationships with fellow volunteers and the community.

8. Able to reduce personal egoism for solidarity with each other.

9. Their presence makes the community more active.

10. Active participation of volunteers in committee activities both in their environment and in the community.

11. Conducting daily routine activities such as teaching and weekly activities such as community service.

In its implementation, was found several factors that supported and inhibited volunteer self-actualization. Several factors that support volunteer self-actualization are divided into internal and external factors [14].

Internal factors are (1) Student's mindset must be versatile which encourages their adaptation to be done well in the community. (2) The character as a student who must be independent, living away from family gives positive impetus values to strengthen selfactualization of volunteers at the service location. (3) A work program that is carried out in a solid and voluntary manner is a good encouragement to consistently run the program at the service location.

While the supporting factors that come from outside are (1) the factor of the friendly Indonesian community with migrants makes it easy for volunteers to be accepted by the 
community so that the program designed can run well. (2) Assistance from community leaders and management who provide prior understanding and socialization to the community so that volunteers feel safe at the location. (3) Their family's belief that the devotion they have will have a positive impact on the development of the personality of the volunteers.

Not only supporting factors, the researchers also found several factors that became obstacles in volunteering themselves: (1) Miscommunication among fellow volunteers which made some programs not run optimally. (2) Some volunteers who are very young and lack experience of living away from family need more time to adapt to the community. (3) The limitations of volunteers in mastering local languages make some volunteers less intense contact with the community.

Maslow in Irwan Hamdi (2016) explains in the theory of self-actualization in more detail the effect on the fulfillment of basic human needs is described as follows [15]:

1. Acceptance and Realism: People who understand and have realistic perceptions of themselves, others and the environment around them.

2. Problem centering: Having a sense of helping others solve their problems or find the most effective solutions to problems. This happens even though problems occur outside themselves or their personal environment. Motivation for his sense of responsibility and social ethics became the basis of his desire.

3. Spontanity: Able to be spontaneous in both thought and behavior. People easily adjust to other people or other environments, social rules, and tend to be open.

4. Autonomy and Solitude: People with self-actualization have higher needs for freedom and privacy.

5. Continued Freshness of Appreciation: People with self-actualization see the world with continued appreciation and admiration. Gratitude for every little experience you get will be a source of inspiration and pleasure.

6. Peak Experiences: People with self-actualization have a peak of self-esteem which Maslow calls joy. After all the experiences he gets, people feel inspired, strengthened, and become better.

Self-actualization has been carried out by volunteers also impacts on their individual resilience. This implication is analyzed to answer the next research question which is the implication of self-actualization on the individual resilience of volunteers. Soemarno Soedarsono (1997) from the National Resilience Institute of Republic of Indonesia in the book Personal Resilience and Family Resilience as a Foundation for National Resilience describes the characteristics of young people who have individual resilience, namely having selfconfidence and holding to principles, free from a sense of dependency but longing for togetherness, having a soul dynamic, creative and never give up and prioritize the public interest rather than personal interests.

First, confident and holding principles. Confidence according to B. Suryosumarto (1997) is basically the ability of a person to convince himself and self-judgment in doing the task and choosing an approach that is felt to be quite effective. Including trust in his ability to face an increasingly challenging environment and confidence in his decisions or opinions [16].

The confidence has existed in each volunteer also influenced their personality in holding principles. Ary Ginanjar Agustian (2017) argues that the principle of life is like a compass which is useful to show the direction that will guide where life will be taken [17].

Second, the independency. Antonius (2002) provides an independent meaning that is able to act according to circumstances without asking or depending on others. Independent is where a person wants and is able to realize his own desires and desires that are seen in real 
actions or actions in order to produce something (goods and services) for the fulfillment of his life and fellow human needs.

According to Maslow (1994) independence or independency is a form of selfactualization which is realized by not relying on others. Steinberg in Rahayu Ginintasi (2009), arranges independence in 3 aspects [18] which is emotional independence, independence of behavior and value autonomy.

Third, dynamic personality, creative, and never give up. Personality according to Nana Syaodih Sukmadinata (2004) is defined as integration between aspects which include psychological aspects such as intelligence, talents, attitudes, motives, interests, abilities, morals and physical aspects such as body posture, height and weight, senses, etc. [19] Wildan Zulkarnain (2013) said, dynamic is something that means power, always moving, developing and able to adjust adequately to the situation.

From interviews and observations conducted by the researchers, the volunteers were very dynamic where they were able to solve various problems both individual and group problems well so that they did not interfere with the process of self-actualization. Living with others who are just known causes volunteers to become accustomed to the diverse character of society. The creative attitude seen in the preparation of work programs isn't always the same as the assessment program from IYALE or from other groups.

The fourth, prioritizing public interests over personal interests. This attitude actually applies absolutely to anyone, especially for the younger generation. Attitudes prioritize public interests over personal interests in line with the mandate of the Pancasila as the basis of the Indonesian state, namely the fifth principle in which the common interests must always be upheld in life as social beings.

Abd Mu'id Aris Shofa (2016) believes personal security for youth is very important because personal security is the initial foundation for the realization of national security [20]. The attitude of student idealism as youth owned by volunteers encourages them to fight for equal rights and serve the community.

\section{CONCLUSIONS}

From the description of self-actualization and individual resilience of IYALE Institute volunteers, the following conclusions can be drawn. The phenomenon of self-actualization of volunteers begins with the fulfillment of basic needs and life motivation in an effort to realize the optimal self-actualization process. In the application of the process, self-actualization can be carried out well in the form of voluntary service activities because these needs have been met.

Nevertheless, there are several obstacles in volunteering for self development but these have no significant effect because these constraints are temporary and can be immediately overcome by volunteers, for example adaptation and how to respond to people and the new environment. In addition there are also several supporting factors both internal and external can strengthen the process of self-actualization of volunteers.

Furthermore, self-actualization that has been carried out by volunteers also affects their individual resilience. With good individual resilience, the reinforcement of good and tough youth character is created. The implication is manifested in having self-confidence and holding to the principle, free from a sense of dependency but longing for togetherness, having a dynamic, creative and unyielding soul and giving priority to the public interest rather than self-interest. 


\section{REFERENCES}

[1] H. Skelsey Guest, Maslow's Hierarchy of Needs, Psychologist. 2018.

[2] Assoc Prof. Dr. Azizi Hj. Yahaya, Abraham Maslow : The Needs Hierachy, Abraham Maslow: The Needs Hierachy, 2008.

[3] Raharjo, Penguatan Civic Literacy dalam Pembentukan Warga Negara Yang Baik (Good Citizen) dan Implikasinya Terhadap Ketahanan Pribadi Warga Negara Muda (Studi Tentang Peran Pemuda HMP PPKn Demokratia pada Dusun Binaan Mutiara Ilmu di Jebres, Surakarta, Jawa Tengah, Jurnal Ketahanan Nasional, vol. 23, pp. 175198.

[4] S. Soedarsono, Ketahanan Pribadi dan Ketahanan Keluarga Sebagai Tumpuan Ketahanan Nasional. Jakarta: Intermasa, 1997.

[5] H. Kaelan, Metode Penelitian Kualitatif Interdisipliner, Yogyakarta: Paradigma, 2012.

[6] M. Idrus, Metode Penelitian Ilmu Sosial: Pendekatan Kualitatif dan Kuantitatif, Jakarta: Erlangga, 2003.

[7] T. Laferriere, Qualitative research: Theory and practice, Humanist Psychology, 1986.

[8] Sugiyono, Metode Penelitian Kuantitatif, Kualitatif dan R\&D, Bandung: Alfabeta, 2013.

[9] Purwanto. 2010. Instrumen Penelitian Sosial dan Pendidikan. Yogyakarta: Pustaka Pelajar.

[10] M. I. Zulkarnain, Peran Balai Pemuda dan Olahraga Yogyakarta dalam Upaya Pengembangan Kewirausahaan Pemuda Untuk Mendukung Ketahanan Ekonomi Keluarga, Jurnal Ketahanan Nasional, vol. 21, no. 3, pp. 197-207, Desember 2015.

[11] S. McLeod, Maslow's Hierarchy of Needs, Simply Psychology, 2012. .

[12] J. W. Altschuld, Needs Assessment, in International Encyclopedia of the Social \& Behavioral Sciences: Second Edition, 2015.

[13] F.G. Goble, Mazhab Ketiga: Psikologi Humanistik Abraham Maslow, Yogyakarta: Kanisius, 1987.

[14] S. B. Kaufman, Self-Actualizing People in the 21st Century: Integration With Contemporary Theory and Research on Personality and Well-Being, Journal Humanist Psychology, 2018.

[15] I. Hamdi, Dinamika Aktualisasi Diri Pemuda Rantau dan Implikasinya Terhadap Ketahanan Pribadi: Studi Pada Mahasiswa Rantau Asal Sumatera Barat di Asrama Putri Bundo Kanduang DIY, Jurnal Ketahanan Nasional, vol. 22, no. 3, pp. 306-320, Desember 2016.

[16] B. Suryosumarto, Wawasan Nusantara dan Ketahanan Nasional Dalam Kehidupan Nasional dan Perencanaan Pembangunan, Jakarta: Bumi Aksara, 1997.

[17] R. F. Rachman, Spirituality through the Images of Nature in 'November Day at Mc Clure's, Nobel Journal Literature Language Teaching, 2015.

[18] R. Ginintasi, Kontribusi Pola Pengasuhan Orang Tua Terhadap Perkembangan Kemandirian dan Kreativitas Anak, Bandung: FIP Universitas Pendidikan Indonesia, 2009.

[19] N.S. Sukmadinata, Landasan Psikologi Proses Pendidikan, Bandung: PT Remaja Rosdakarya, 2004.

[20] A. M. A. Shofa, Peran Pemuda dalam Pendampingan Mahasiswa dan Implikasinya Terhadap Ketahanan Pribadi (Studi di Pusat Layanan Difabel UIN Sunan Kalijaga, Jurnal Ketahanan Nasional, vol. 22, no. 2, pp. 199-216, Agustus 2016. 